\title{
Religion and Early German Romanticism
}

Jacqueline Mariña

For the early German Romantics, religion must be understood in terms of consciousness, that is, in terms of what consciousness is and what it is not, namely, that which grounds consciousness but exceeds it capacity for self-reflection, and therefore, for knowledge. Prior to Kant, metaphysics and theology concerned themselves with ultimate objects such as God and the soul in a naïve sort of way, without taking into account the problem of how consciousness conditions our capacity to know such objects. With Kant and after him, the objects of religion become problematized precisely because they had to be understood in relation to consciousness, and the objects of consciousness are limited to the conditioned, phenomenal realm. Kant, as is well known, saved the objects of faith by making them necessary suppositions of practical reason: the person of good will, acting as she must in the context of finitude and its uncertainties, must hope that there is a God and think of her own existence as endless. Schleiermacher, a member of the Jena constellation of early Romantics, would complain that this relegated religion to a mess of "metaphysical and ethical crumbs." ${ }^{1}$ Instead he, and other important figures working out the reception of Kant, would understand religion in terms of an analysis of consciousness and its conditions, namely, in relation to the Absolute. Religious song, myth, and dogma are the result of the "outpourings of the inner fire;" ${ }^{2}$ they are expressions of a feeling at the ground of the soul in which the self grasps itself in the infinite. Religious experience is an inchoate reflection of consciousness on itself and its origins. The reception of Kant's theory of consciousness and its relation to religion was marked by two fundamental strategies. The first was that of the early Romantics: Novalis, Schlegel, Schleiermacher, and Hölderlin, for whom the Absolute exceeds all possibility of conceptualization. The other was of the German

${ }^{1}$ Friedrich Schleiermacher, On Religion: Speeches to its Cultured Despisers, translated by John Oman, New York: Harper, 1958, p. 31. This is a translation of the 1821 (third edition) of the Speeches. However, for the most part this essay will focus on the first (1799) edition of the Speeches, Friedrich Schleiermacher, On Religion: Speeches to its Cultured Despisers, translated and edited by Richard Crouter, Cambridge: Cambridge University Press, 1988, 1996. Henceforth each edition will be indicated by the name of the translator.

${ }^{2}$ Speeches (third edition, Oman translation) p. 216; first edition (Crouter translation) p. 99. 
Idealists, Fichte, the early Schelling, and Hegel, for whom possibility, and hence the logic that makes possibility intelligible, precedes actuality and thereby conditions the ground of Being itself. The import of the strategy of the early Romantics can only be understood in relation to the approach of which they were deeply critical, an approach that would culminate in the absolute philosophy of Hegel.

\section{Historical Preliminaries}

Dieter Henrich has righty called the last two decades of the $18^{\text {th }}$ Century the classical age of German philosophy. The first edition of Kant's Critique of Pure Reason had appeared in 1781 and the second in 1787, the Critique of Practical Reason in 1788, and the Critique of Judgment in 1790. With the appearance of Kant's major works, philosophy was never the same. No serious philosopher could ignore it. Immediately controversies ensued on how it was to be received and interpreted, and figures such as Karl Leonhard Reinhold and Johann Gottlieb Fichte made important attempts to perfect Kant's transcendental idealism, making it more "scientific" and systematic by grounding it in a single self-evident first principle. Whether or not these efforts remained true to the critical philosophy (Kant himself thought they were not), they were undeniably inspired by it. As Henrich notes, between 1789 and 1798 "all the fundamental decisions crucial to ensuing developments had been made," ${ }^{3}$ that is, all points of departure stemming from Kant's insights and their trajectories had been mapped out. During this period, the University of Jena became a central hub for the dissemination of Kant's philosophy. Karl Reinhold and Carl Christian Erhard Schmid, both well know expositors of Kant's work, taught there, and the Jenaer Allgemeine Literaturzeeitung, an important journal whose purpose was to disseminate and discuss Kant's philosophy, was edited there as well. In 1794 Fichte, himself impressed with Reinhold's call to systematize transcendental idealism, succeeded him in the chair devoted to Kant's philosophy. Such was the context of the Jena constellation of early Romanticism, a group of friends that included Novalis (Georg Friedrich von Hardenberg), Friedrich and Wilhelm Schlegel and Friedrich Schleiermacher, among others. They came together during the period between 1796 and 1800 in Jena and Berlin, often congregating at the house of the Schlegel brothers in Jena. The group engaged in lively philosophical

${ }^{3}$ Dieter Henrich, The Course of Remembrance and Other Essays on Hölderlin, edited by Eckart Förster, Stanford: Stanford University Press, 1997, p. 93; cf., p. 73. 
conversations that included the topic of Kant's philosophy and the new attempts to systematize it. The result was a prodigious literary and philosophical production by many of its members. The group also produced the journal Das Athenäum, published between 1798 and 1800. Manfred Frank rightly expands the circle of early German Romantics to include Friedrich Hölderlin, even though he was only at Jena for six months in 1794-5, and that aside from a meeting in May with Novalis in the home of Niethammer, there seemed to have been little contact between Hölderlin and his friends and the Jena group. Nevertheless, there are striking similarities in their critical reactions to the philosophy of first principles as laid out by Reinhold in his Attempt at a New Theory of the Human Faculty of Representation (1789) and by Fichte in the first paragraphs of the Jena Wissenschaftslehre. As Frank notes, these common strategies criticizing the philosophy of first principles had their root in the discussions that took place among Reinhold's students beginning in 1792;4 Jacobi's philosophy, especially as laid out in his second (1789) edition of On the Doctrine of Spinoza, was also particularly influential. ${ }^{5}$ The philosophical principles developed by the Romantics concerned not only the ontological nature of consciousness and its metaphysical ground, but had important consequences for the theory of religion. The most important figure in this regard is Friedrich Schleiermacher (1768-1834) whose first edition of On Religion burst on the scene in 1799 (the book was revised in 1806, 1821, and reissued in 1831), and who is best well known for his magisterial systematic interpretation of Christian theology, The Christian Faith(Glaubenslehre), appearing in two editions, the first in 18212 , and the second in 1830-1. In this essay I first discuss the most important philosophical principles of early German Romanticism, and in the second I discuss the way these views were developed by Schleiermacher in his theory of religion and rethinking of the Christian faith.

The Reception of Kant's Groundbreaking Theory of Consciousness

Why did the early German Romantics resist the philosophy of first principles and the speculative idealism to which it led? In order to grasp what was at stake we must first turn to the groundbreaking claims of Kant's Critique of Pure Reason.

\footnotetext{
${ }^{4}$ Manfred Frank, The Philosophical Foundations of Early German Romanticism, translated by Elizabeth Millán-Zaibert, Albany: State University of New York, 2004, p. 26.

5 Ibid. 55-75.
} 
Famously, Kant had declared in $\$ 16$ of the second edition, “The I think must be able to accompany all my representations, for otherwise something would be represented in me that could not be thought at all ... ” (B 132). Since this I think must be able to accompany my representations, it is itself a reflected representation, and must be distinguished from the original activity of consciousness. ${ }^{6}$ In other words, this I think must be capable of being an intentional object of awareness: I must be able to become self-aware by having myself as an object of cognition if I am to be capable of knowing a representation as my own. In The Christian Faith, Schleiermacher would later refer to this as a "duplication of consciousness," and base his exposition of the nature of the immediate self-consciousness on an analysis of it. ${ }^{7}$ We have then two elements of consciousness, each equally necessary for its possibility, the reflecting activity of consciousness, and the reflected states through which it becomes aware of itself. With regard to these two elements Kant notes:

But how the I that I think is to differ from the I that intuits itself (for I can represent other kinds of intuition as at least possible) and yet be identical with the latter as the same subject, how therefore I can say that I as intelligence and thinking subject cognize myself as an object that is thought, insofar as I am also given to myself in intuition, only, like other phenomena, not as I am for the understanding but rather as I appear to myself, this is no more and no less difficult than how I can be an object for myself in general and indeed one of intuition and inner perceptions. $(\mathrm{B} 155)^{8}$

This implies that there are two ways that the self is conscious of itself: one in which the self appears to itself in intuition, and the second the self's original factical self-presence to itself in its activity of synthesis. Importantly, regarding the latter Kant claims, "In the transcendental synthesis of the manifold of representations in general, on the

${ }^{6}$ I discuss Kant's understanding of consciousness in significant depth in "Transcedental Arguments for Personal Identity in Kant's Transcendental Deduction,” Philo 14 no. 2 (Fall/Winter 2011: 109-135.

${ }^{7}$ For a more in-depth discussion of this point see my "Where Have all the Monads Gone? Substance and Transcendental Freedom in Schleiermacher," Journal of Religion, Volume 95, No 4, October 2015, 477-505, especially 498-9.

${ }^{8}$ Immanuel Kant, Critique of Pure Reason, Paul Guyer and Allen Wood, translators, Cambridge: Cambridge University Press, 1999. All references to Kant's first Critique are to this translation, 
contrary, hence in the synthetic original unity of apperception, I am conscious of myself not as I appear to myself, nor as I am in myself, but only that I am” (B 157). It can be argued that part of the problem of the transcendental deduction was to show how the I think that can accompany my representation $\mathrm{x}$ (a reflected representation) can be thought to be identical with the activity of thinking that grounds all my representations: how do we identify the two? This is particularly a problem because Kant recognized, following Hume, that the I think has no content of its own.

Kant's followers, however, focused on another problem, namely original consciousness itself and its relation to the reflected I. In his Jena Wissenschaftslehre Fichte famously claimed that "the I posits itself as an I;" the claim, which stands as Fichte's first principle, has to do with the relation of original consciousness, namely the activity of synthesis, to the reflected self. Through its activity original consciousness reflects on itself, and thereby posits and achieves itself. This is not a fact, but an act, a Tathandlung of which we are immediately existentially aware in the very act of reflective self-awareness. The Tathandlung is given through what he called an "intellectual intuition.” Following Kant, he called it an intuition because it is immediate and not a reflected representation; it is, however, intellectual, since it has to do with the synthetic activity of consciousness. But Fichte went even further than this, for he argued that this original consciousness must also be the source of the objects that are the counterpart of the subject's self-awareness. The I cannot reflect on itself as an I, and thereby posit itself, unless the non-I is also posited, for a subject is no subject without an object that is other than itself. Here he no doubt partially took inspiration from Reinhold's principle of consciousness. Consciousness is what it is through its activity of representing. But this implies that if a subject is to have a representation, this representation must not only be understood as a representation of the subject who has it, but equally must be referred to an intentional object. ${ }^{9}$ However, Fichte conceived of representation through an added twist. He argued that "consciousness of the object is only a consciousness of my production of a presentation of the object" and therefore that "all consciousness is

\footnotetext{
${ }^{9}$ So Reinhold, "in consciousness, the subject distinguishes the representation from the subject and the object and relates the representation to both." Karl Leonhard Reinhold, Contributions toward Correcting the Previous Misunderstandings of Philosophers, Vol. I (1790) 167; cited from Dan Breazeale's article "Karl Leonhard Reinhold" in the Stanford Encyclopedia of Philosophy.
} 
only. . . a consciousness of myself..."10 Original consciousness is thereby the origin of both the subject and the world that stands in opposition to it, and as Fichte would claim, "In finding myself I find myself as subject and object, which, however, are immediately connected." This connection between subject and object is given at the origin of representation itself, that is, there is an original moment before the subject-object split that grounds both the subject's awareness of itself as having a representation (the representation as a mere content of consciousness) and the representation as referring to an intentional object. Fichte admits that consciousness of this identity is impossible, for "I am always conscious only on condition that that which is conscious and that of which there is consciousness appear distinct from each other"(48). Nevertheless, this original moment must be presupposed.

We are now well on our way to absolute idealism, although there are still other crucial presuppositions needed to get there. But what is important here thus far is that with these moves Fichte believed he had decisively shown that access to all possible objects of experience lies in consciousness, and that there is a pre-thetical unity to self and world. Totality, therefore, already lies at the ground of consciousness, or at least is given in it in some way. It is given to that moment inaccessible to reflection where self and world are one, that is, in original consciousness. The early German Romantics would have followed Fichte this far. There will, however, be a serious bone of contention between the Romantics and German Idealism, and it concerns the character of this original consciousness itself.

Highly influential in this debate were the views of Friedrich Heinrich Jacobi (1743-1819) whose 1799 Open Letter to Fichte, in which he argued that Fichte's transcendental philosophy amounted to nihilism, put the last nails in the coffin of Fichte's reputation, ultimately leading to Fichte's forced resignation from his chair at Jena. Jacobi's first edition of On the Doctrine of Spinoza, in which Jacobi alleged Lessing had confessed to him that he was a Spinozist, had appeared in 1795, and caused an uproar. There Jacobi argued that Spinoza was the most consequent of philosophers, and that the principle of sufficient reason inevitably leads to the annihilation of human individuality and freedom, and ultimately to atheism. In 1787 he published his book

${ }^{10}$ Johann Gottlieb Fichte, The Vocation of Man, translated by Peter Preuss, Indianapolis: Hackett: 1987, pp. 44-5. While the book appeared in 1800, it was a defense and popularization of Fichte's already published views. 
David Hume on Faith, or Idealism and Realism, attached to which was an appendix containing an influential critique of Kant, whose revised edition of the Critique of Pure Reason had just appeared. Important here, however, is that in the book Jacobi attempted to develop an iteration of transcendental philosophy that avoided the distasteful subjectivism he found in the Kantian version. ${ }^{11}$ But a version of transcendental philosophy it was. He too was concerned with the nature of subjectivity, and he argued, against classical empiricism, that there can be no subject without an object. But for Jacobi subject and object are immediately given. As he notes in his David Hume:

The internal consciousness and the external object, must be present both at once in the soul even in the most primordial and simple of perceptions - the two in one flash, in the same indivisible instant, without before or after, without any operation of the understanding - indeed without the remotest beginning of the generation of the concept of cause and effect in the understanding. ${ }^{12}$

Importantly, what this means for Jacobi is that the division between subject and object is not the result of reflection, but is given prior to it. Representation in a concept presupposes the immediate intuition of the object, and this means that the constitution of the object cannot depend on reflection. In fact, Jacobi claims, in this moment of immediacy there are no representations; rather, "they make their appearance only later on in reflection, as shadows of the things that were formerly present" (277). This constitutes his realism.

Just as important is Jacobi's theory of revelation. In 1789 On the Doctrine of Spinozo Jacobi declared "the greatest service an investigator can do is to uncover and reveal being (Dasein)....[italics mine]"13 This revelation, he argued, must be given to us in unmediated cognition, that is, through feeling. Without it, our knowledge would be baseless, for each proposition would depend for its justification on another proposition, which would in turn require its own, and so on in an endless regress. If the regress is to be stopped, and knowledge is to be possible, there must be a fact that is given to

${ }^{11}$ On this point see George di Giovanni, Freedom and Religion in Kant and his Immediate Successors, Cambridge: Cambridge University Press, 2005, 77.

12 Friedrich Heinrich Jacobi: The Main Philosophical Writings and the Novel Allwill, translated by George di Giovanni, Montreal: McGill-Queen’s University Press, 1994, 277.

${ }^{13}$ Jacobi, On the Doctrine of Spinoza (1789), 42; cited in Frank, 70. 
consciousness immediately, and that is the immediate factum of our own existence and its dependence on the unconditioned. This is a groundless, unjustified cognition needing no justification. It is given in feeling (a kind of self feeling), or what Jacobi also calls belief [Glauben]. While Kant took issue with Jacobi’s equation of this self feeling with Glauben, Jacobi certainly followed Kant in characterizing the original cognition in terms of feeling: the Dasein or existence of things can only be given through sensation, and not through a concept. Hence Kant notes that "perception, which yields the material for a concept, is the sole characteristic of actuality" (A225/B272-3), and "I cognize existence through experience (Reflexion 5710, AA 18: 332). ${ }^{14}$ Yet more to the point, regarding the self's awareness of itself, Kant explicitly notes "the "I think is, as has already been said an empirical proposition" (B422, note). ${ }^{15}$ For his part, Jacobi referred the unmediated feeling of Being to Kant's "transcendental apperception," 16 and noted, "of our existence (Dasein), we have only a feeling, but no concept."17

For Jacobi, Being is revealed, and in this revelation faith is born. And while Jacobi might seem an irrationalist for all his talk of the "salto mortale" into the arms of the divine mercy, he did, in fact have powerful arguments for his position. An important argument is closely related to the one noted above regarding the endless regress of propositions that depend upon others for their justification. Only if something is given, and given immediately with Cartesian certainty through experience, is the regress stopped and a foundation for knowledge achieved. The ideas are nicely presented in a letter he wrote to Mendelssohn, and which he reproduced in the book on Spinoza:

We are all born in faith and must remain with this faith, just as we are all born in society and must remain within society.... How can we strive for certainty when certainty is not known to us in advance; and how can it be know to us, other than through something that we already recognize with certainty? This leads to the concept of an unmediated certainty, which stands in no need of explanation (Gründe), but rather excludes all such explanation, and solely and

\footnotetext{
${ }^{14}$ Immanuel Kant, Notes and Fragments, translated by Curtis Bowman, Paul Guyer and Frederick Rauscher, Cambridge: Cambridge University Press, 2005, p. 294.

${ }^{15}$ On these points see Frank, 63.

${ }^{16}$ Cited in Frank, Philosophical Foundations, 64.

17 On the Doctrine of Spinoza (1789) 420, note; cited in Frank, Philosophical Foundations, 64; Giovanni, Jacobi, 374.
} 
alone is the corresponding representation itself of the represented thing. Conviction based on argument is secondhand conviction.... The conviction which these bring about arises from a comparison and can never be totally certain or complete. If faith is an act of holding something to be true without relying upon argument, then the very security we place in arguments of reason must be rooted in faith (Glaube) and so arguments of reason must take their strength from faith. ${ }^{18}$

This is an extraordinary argument: our very capacity to trust our reason and our ability to carry out valid arguments must depend on an unmediated foundation whose certainty is beyond the need for argument, for through argument we cannot ascertain our capacity for valid argument. Rather, this certainty is given in unmediated selffeeling and its correlate, the unconditioned. Importantly, Jacobi also argues that with every conditioned the unconditioned is also given, and that we have just as great a certainty of the unconditioned as we have of our own existence. In fact, we have an even greater certainty of the unconditioned! ${ }^{19}$ Importantly, it is in this certainty of the unconditioned that we know God.

Since everything that lies outside the complex of the conditional, or the naturally mediated, also lies outside the sphere of our distinct cognition, and cannot be understood through concepts, the supernatural cannot be apprehended by us in any way except as it is given to us, namely, as fact -IT is! This Supernatural, this Being of all beings, all tongues proclaim GOD. ${ }^{20}$

Now, while we have a Cartesian certainty of God given in immediate experience, it also follows that due to this immediacy we can have no discursive understanding of Being. For it lies prior to reflection, and as such "cannot be understood through concepts," which as such are always mediated by reflection. Reflection always presupposes Being, although it cannot penetrate it.

This means that for Jacobi actuality always precedes possibility, the latter of which can only be grasped through concepts. On this point Jacobi was influenced by

${ }_{18}$ On the Doctrine of Spinoza (1789) 215f.; cited in Frank, 204.

19 On the Doctrine of Spinoza (1789) 423, Giovanni, Jacobi, 375.

${ }^{20}$ On the Doctrine of Spinoza 427; Giovanni Jacobi, 376. 
Kant's pre-critical essay from 1763, The One Possible Basis for a Demonstration of the Existence of God. ${ }^{21}$ There Kant had argued that existence must precede possibility: “...the phrase 'nothing exists' is synonymous with 'there is nothing at all;' and it would be pretty contradictory to add in spite of this that something would be possible (AA 11:78). But if actually precedes possibility, the actual cannot itself be comprehended in terms of the possible. Our only access to it is a factical one: IT IS. We apprehend Being through the immediacy of feeling. And this is the revelation of Being that Jacobi sought to express. Being could not be proved through a series of inferences, it could in no way be known discursively, it could only be revealed.

This, as we shall see, was Jacobi's legacy to Romanticism, and from it much followed. ${ }^{22}$ But right from the start we can already glean how seriously Jacobi departs from Fichte's insights, and why the dispute between them became a central contention of the period. Through his foundational starting point, "the I posits itself as an I," Fichte emphasized the activity of self-positing through which the self achieves its existence. This activity, moreover, had a definite structure, namely the structure through which the I determines itself through reflection. The process of reflection therefore, becomes the necessary condition of the achievement of the I. Jacobi, on the other hand, emphasized the factical quality of immediate consciousness: the self simply finds itself in existence, and this is an empirical proposition. Moreover, the self that is immediately encountered is a radically conditioned self, and in this immediate encounter the self also encounters that upon which it is radically dependent. This is the foundation of Jacobi's realism, one that would also be adopted by Schleiermacher. All of this was not lost on Jacobi, who in his 1799 Open Letter to Fichte called him an inverted Spinozist: inverted because in his system reflection, and not substance, was the foundational principle of all reality, and a Spinozist, because this was, indeed, the one principle behind all reality. There could not have been a more apt characterization of Fichte's idealism than that which Jacobi reports as having occurred to him in a "mischievous moment." In the letter Jacobi compares Fichte's idealism to a knitted stocking. The stocking "attained actuality through the mere back and forth movement of the thread ...." The flowers, borders and figures woven into the stocking were "nothing but a product of the

${ }^{21}$ On this point see Giovanni, Freedom and Religion, 85-6, and Frank 68.

22 The centrality of Jacobi's influences on Romanticism are documented by Frank in his chapter "The Unknowability of the Absolute," in Philosophical Foundations, 55-75. 
productive imagination of the fingers hovering between the I of the thread and the not I of the stitches." But, Jacobi emphasized, the stocking "is still only its thread," and the thread "only need return to its original identity by exposing the rows of its reflections in order to make it visibly apparent that that infinite manifold, and manifold infinity, was nothing but a empty weaving of its weaving, and that the one single reality is only itself with its self-initiated, self-contained, and self directed activity." ${ }^{23}$ And with such and an apt and witty metaphor, Jacobi sealed Fichte's fate. Fichte already stood accused of atheism. Jacobi's image not only made Fichte look ridiculous, it also exposed his system as portraying humanity as autonomously creating castles out of thin air, so to speak, through a "self-initiated, self-contained, and self directed activity." This was certainly atheism, or at the very least a philosophy with no need for God. To be sure, Jacobi had not been entirely fair to Fichte. In the Wisshenschaftslehre Fichte had already argued that there must be a moment of immediacy grounding reflection. But the damage had been done, and Fichte's reputation would never completely recover.

Jacobi’s arguments were decisive for early German Romanticism. His writings, and his Open Letter in particular drew attention to Fichte's problematic claims for the self-sufficiency of self-consciousness. It was, however, the Romantics who worked out the philosophical deficiencies of this view, as well as the implications of their metaphysical claim that self-consciousness depends on Being. Being or actuality cannot be known in terms of reflective judgment, since it precedes it as its condition. As Frank so aptly notes, "the basic conviction common to the early German Romantics...consists in the supposition that Being - as the simple seamless sameness (Einerleiheit), in contrast to the identity of the Kantian-Fichtean cogito - cannot be understood on the basis of the relations of judgment and reflection, all of which are occupied with reuniting original divisions and can always merely presuppose an original simple unity." ${ }^{44}$ This priority of Being (Dasein) over reflection constitutes the basic realism at the heart of German Romanticism. It amounts to, as Frank would put it, a "re-Kantianization" 25 of German philosophy, that is, Romanticism's insights were fundamentally more true to Kant's critical philosophy than the revisionary moves undertaken by Fichte and those who worked these out to their ultimate conclusions, culminating in Hegel's absolute

${ }^{23}$ Giovanni, Jacobi, 509.

${ }^{24}$ Frank 125.

${ }^{25}$ Frank, 97. 
philosophy. In what follows I sketch out the most powerful of the Romantic critiques of the philosophy of first principles and their implications. These have to do with the following themes, all intrinsically connected: 1) The priority of Being over reflection; 2) the nature of identity; 3) epistemological modesty and the impossibility of an absolute philosophy of first principles. I begin with Hölderlin's famous fragment, written possibly as early as $1775,{ }^{26}$ "Judgment and Being" because it constitutes a singular and remarkable self-sustained argument making intelligible arguments by the other Romantics, many of which can only be found in fragments.

In the fragment Hölderlin echoes important themes from both Jacobi and Kant, in particular Jacobi's insistence that actuality must precede possibility: "Actuality and possibility are distinguished, just as mediated and unmediated consciousness. If I think a thing as possible, then I only repeat the previous perception, through whose power it is actual. There is for us no thinkable possibility that was not actuality. For this reason the concept of possibility is not at all valid of the objects of reason...." 27 Possibility is given only to mediated consciousness, that is, consciousness in which the self is conscious of itself, and can therefore reproduce perceptions and form concepts. As Kant made clear, concepts are always mediated representations, for they depend on the capacity of consciousness to make itself its own object, which is the condition of its capacity to grasp the multitude of intuitions that can fall under a concept as its own possible intuitions. We grasp the possible through concepts, and this means that our grasp of what is possible not only depends on the mediation of consciousness, this grasp itself depends on the actuality of consciousness. Furthermore, here Hölderlin also echoes Jacobi's empiricist insistence that actuality must precede our capacity to represent: imagining the possible depends on our capacity to reproduce the material that has already been given to perception. But in his discussion of mediated and unmediated consciousness and of the conditions of the possibility of judgment, Hölderlin goes beyond mere empiricist principles. His claim that the concept of possibility "is not at all valid of the objects of reason," is of enormous significance. Here he lays out one of the paths forward stemming from Kant's critical philosophy and analysis of consciousness;

${ }^{26}$ On this point see Henrich, "Hölderlin on Judgment and Being," 71-89, in Henrich, The Course of Remembrance.

${ }^{27}$ Friedrich Hölderlin, Sämtliche Werke, Stuttgart: 1943-1985, Bd. 4, Seite $216 f$. All translations of Hölderlin's fragment are my own. 
the other path would find its ultimate expression in Hegel's absolute philosophy. Possibility depends on mediation, on the activity of consciousness, and therefore on its actuality. Hence Being (Dasein) precedes possibility, which is only intelligible in terms of mediated consciousness. And if this is the case, there is no path forward for a philosophy of the Absolute, that is, a philosophy that can grasp the inner workings and fate of the totality of existence. Reason cannot grasp this totality. For consciousness cannot penetrate the conditions of its own actuality. Our grasp of the conditions of determination are not applicable to it, and neither is the principle of sufficient reason. It IS, pure and simple. Because it cannot be penetrated, it can only be an object of belief, not of knowledge. As Novalis would note, echoing Jacobi: "Access to the unconditioned is given in Belief: what I don't know, but I feel, [. . . I I believe" (NS II: 105).28 As we shall see, these ideas would become the basis of Schleiermacher's theology. For Fichte, the early Schelling, and then Hegel, on the contrary, the ontological conditions of the possibility of determination, which are purely logical, precede determination, and, therefore, actuality. The I determines itself, and thereby achieves actuality, through opposition with the not-I; Hegel would expand this principle of the logical conditions of determination to one governing the inner possibility of the actualization not only of the I, but of absolute Mind itself. Being presupposes thought, and for this reason logic must precede nature in Hegel's system.

The rest of Hölderlin's fragment engages the early Schelling. In a famous passage of the Ich Schrift, Schelling exclaimed: "I am! My I contains a Being that precedes all thinking and representing. It is insofar as it is thought, and it is thought because it is . . . This, in turn, is precisely because it is and is thought only insofar as it thinks itself (SW 1/1: 167). ${ }^{29}$ For Schelling the Absolute I achieves existence precisely through its thinking of itself, and as such, conditions of the activity of thinking condition actuality. Hölderlin would take issue with this. Using Fichte's terminology, he calls original consciousness "intellectual intuition," and agrees with Fichte and Schelling that "subject and object are intimately united in intellectual intuition." All judgment depends on an original division "through which subject and object are first possible." Further, he argues, "in the concept of this division there already lies the

${ }^{28}$ Cited in Frank, 34.

29 Cited in Frank 89. 
concept of the relation of object and subject opposing one another, and the necessary presupposition of a whole, of which object and subject are parts." The issue, however, is how we are to think of this whole. Is this whole something that achieves itself through thinking?

Hölderlin continues, "I am I is the most fitting example of this judgment," that is, self-consciousness is achieved through an original judgment in which I recognize myself as the thinker of my thoughts. This original judgment makes all other judgments possible. But in what way is judgment an achievement of an I of original consciousness? What is it that is contained in original consciousness anyway? Here the problem Kant had recognized in the first Critique, but had glossed over (B 155), becomes the central issue dividing Romanticism from Idealism:

Where subject and object are absolutely, not merely partially unified, in such a way that no division could be presupposed without damaging the essence of that which is to be divided, there in no other way can we speak about absolute Being, as is the case in intellectual intuition.

Yet this Being should not be confused with identity. If I say: I am I, then the subject (I) and the object (I) is not unified in such a way that no division could be presupposed without damaging that which is to be divided; on the contrary, the I is only possible through this division of the I from the I. How can I say I! without self-consciousness? How is then self-consciousness possible? It is possible through opposing myself to myself, dividing myself from myself, but in spite of this division I recognize myself in opposition as the same. But to what extent the same? I can, I must question this, for in another respect it [the self] is opposed to itself. Therefore identity is not a unification of subject and object that takes place absolutely, therefore identity is not $=$ Absolute Being. ${ }^{30}$

Holderlin's insightful critique of Schelling is that he has put the cart before the horse; he has presupposed what he has been trying to prove. Mere Absolute Being, given as it is pre-thetically, cannot be thought of in the same way as one would an object of consciousness. It cannot be thought of as having "parts" that are distinguishable from one another prior to the division that occurs through self-consciousness and then later

${ }^{30}$ Hölderlin, SW, 4. 216 , translation mine. 
identified with one another after the division; this would injure its absolute unity. Knowledge of the I, the capacity to make a judgment about it, is dependent on selfconsciousness. And self-consciousness is dependent on original consciousness. In order to make the judgment I am I, I must already have identified original consciousness with the I. But any knowledge of an I depends on the original division that gives rise to selfconsciousness, so original consciousness cannot be singled out as an Absolute I that is then somehow identified with the reflected I. The original unity is not the Absolute Being of an I; the unity between the I and the not I is not a product of the activity of thinking and willing. It transcends it and is given in Being. Moreover, the judgment of identity cannot lie at the heart of Being. Being remains dark to consciousness, an enigma.

Novalis, too, was deeply aware of the implications the differences between thetic and pre-thetic awareness had for a philosophy of Being. He begins his set of fragments entitled Pollen with the line "Everywhere we seek the unconditioned, but find only things." ${ }_{11}$ All our knowledge is mediated through the reflected I of self-consciousness, which is conditioned not only by the not-I, but by original consciousness itself. Unconditioned Being can only be given in original consciousness, and as such cannot be accessed through concepts and judgment, and thus through knowledge. A related idea is expressed in his fragment, "We leave the identical in order to represent it," (NS II: 104, Nr. 1), that is, once consciousness has reflected upon itself it has lost its identity, and in fact, there is never a complete identity between original consciousness and its successive reflections. Each reflection is only a partial snapshot of the activity of original consciousness, and as such cannot capture it. Consciousness, argued Novalis, "is not what it represents, and does not represent what it is" (NS II: 226, Nr. 330). ${ }^{32}$ Truth, then, can only be grasped through successive approximations, that is, through a synthesis of past moments of reflection with successive new ones. Each reflection encompasses self and world (I and not I), for the world that is known is the world that is

${ }^{31}$ Novalis: Schriften, Vol. II, edited by Paul Kluckhohn and Richard Samuel, Stuttgart: Kohnhammer, 1960 ff, 412, Nr. 1. An English translation can be found in Novalis: Philosophical Writings, translated and edited by Margaret Mahony Stoljar, Albany: State University of New York Press, 1997, 23.

32 An English translation can be found in Novalis: Fichte Studies, Jane Kneller, ed. and trans., Cambridge: Cambridge University Press, 2003, 123. On this point see also Frank, Philosophical Foundations, 172ff. 
known as given to consciousness. And each reflection must be brought together with other ones in the temporal manifold. How do I know that a representation is valid of an object? Only if I can integrate it coherently with others that have been attributed to it. Since the world is given to consciousness through an infinite series of apprehensions of self and world, there can never be a definitive grasp of what is objectively true. Our understanding of the world must be infinitely revisable. Here we have the beginnings of a theory of truth that would be only fully worked through by Husserl.

Given these considerations, an absolute philosophy rooted in foundational first principles is out of the question. There is, furthermore, no absolute knowledge. There is only coherence and successive approximations. Since we cannot provide a foundation to philosophy on which all knowledge can be grounded modo geometrico, philosophy can only begin in the middle. Friedrich Schlegel eloquently noted that, "our philosophy does not begin like the others with a first principle-where the first proposition is like the center or first ring of a comet-with the rest a long tail of mist-we depart from a small but living seed-our center lies in the middle."33 Schleiermacher too, noted the impossibility of beginning with first principles when he noted in his Dialektik "Beginning in the middle is unavoidable." ${ }_{34}$ This middle is the actuality of human existence and its commitments; from them we argue backwards and forwards, from the terminus a quo to the terminus ad quem, never, however, completing the synthesis, but ever coming closer to it through successive approximations.

\section{Schleiermacher and the Philosophy of Religion}

It was Friedrich Schleiermacher who systematically worked through the important hints we found in the thought of Jacobi, Novalis, and Hölderlin for a systematic theory of religion and the fundamental principles of a Christian theology. Against Idealism and the philosophy of first principles, Schleiermacher stands firmly on the side of the re-Kantianization of philosophy: original consciousness and its ground cannot be penetrated by thought. It is, in fact, cognized only through feeling. In his Dialektik Schleiermacher asks, "How does it [the immediate self-consciousness] relate to

Fridrich von Schlegel, Kritische Ausgabe, edited by Ernst Behler, Paderborn: Schoenigh, 1958) KA XII, p. $328 .^{33}$

${ }^{34}$ Friedrich Schleiermacher, Dialektik (1814-15), Einleitung zur Dialektik (1833), ed. Andreas Arndt. Philosophische Bibliothek. Vol. 335. Hamburg: Felix Meiner, 1988, 105. 
the transcendental ground?" He answers, "We consider the latter to be the ground of the thinking being in regards to the identity of willing and thinking. The transcendental ground of thought precedes and succeeds all actual thinking in an atemporal manner, but never itself becomes thought." 35 Original, immediate consciousness can never become an object of thought; its operations are only partially reflected in the self's awareness of itself. The Absolute transcends consciousness so thoroughly that it "does not come to an appearance at any time." Moreover, consciousness of God is not given directly in the immediate self-consciousness. What is given directly is consciousness of the self as absolutely dependent. Co-posited along with this consciousness is the Absolute itself. Here, no doubt, we hear echoes of Jacobi, who had argued that along with the conditioned the unconditioned is always also coposited. While there are no doubt significant differences between the two men, Schleiermacher was significantly influenced by Jacobi. He had even toyed with dedicating the first edition of Christian Faith to him, but changed his mind when Jacobi died in $1819 .{ }^{36}$

Schleiermacher first brought these ideas to bear on the problem of religion in the first edition (1799) of his On Religion: Speeches to its Cultured Despisers. Contra both Kant and Fichte, he argued that religion was not ethics and was no mere ethical postulate; moreover, it cannot be based on the all too human enterprise of metaphysics. Kant's philosophy had made impossible a naïve speculation about the nature of things in themselves, and God cannot be an object of consciousness in opposition to a subject, for all objects of consciousness are finite and conditioned by the subject. Religion "does not wish to determine and explain the universe according to its nature as does metaphysics; it does not desire to continue the universe's development and perfect it by the power of freedom and the divine free choice of human being as does morals. Religion's essence is neither thinking nor acting, but intuition and feeling" (Crouter, 22). To think of religion merely in terms of the hopes of the morally committed individual, as Kant had done in his Religion within the Limits of Reason Alone, is to miss its fundamental character. Genuine religion can be found only at the heart of consciousness. We have

${ }^{35}$ Friedrich Schleiermacher, Vorlesungen über die Dialektik, KGA, II.10.2, 568.

${ }^{36}$ On this point, as well as a discussion of the differences between Schleiermacher and Jacobi, see Richard Crouter, Friedrich Schleiermacher: Between Enlightenment and Romanticism, Cambridge: Cambridge University Press, 2005, pp. 77-80. 
already witnessed both Jacobi and Novalis referencing the feeling of Being given through the self s immediate awareness of itself: faith or belief is directed towards the ground of the self who cognizes its own existence immediately, through feeling. Schleiermacher would develop these ideas further in Christian Faith: we cannot know this ground, but we feel our conditioned existence and have faith in the unconditioned that sustains it.

In On Religion Schleiermacher makes a groundbreaking move for philosophy of religion and theology: he claims that the basis of all religion and theology is religious experience, and for this reason the category of religion is sui generis. Schleiermacher notes the purpose of the Speeches: "I wish to lead you to the innermost depths from which religion first addresses the mind" (10). The journey to these depths will allow us to consider "religion from its center according to its inner essence" (12). The basis of religion is decidedly not an "objective revelation" whose significance can be codified in dogmatic propositions that must be accepted as a condition of salvation. Whatever revelation there is given along with the feeling of Being, that is, along with the immediate awareness of one's own finite and conditioned existence. Whoever does not have this experience will remain blind to the true nature of religion; religion is a "scandal or folly" for the individual who has not experienced it herself firsthand; "the matter of religion is so arranged and so rare that a person who expresses something about it must necessarily have had it" (9). The "spiritual material" for this experience "lies latent" in the soul of all individuals, and develops from this material in the more advanced: "It springs necessarily and by itself from the interior of every better soul, it has its own province in the mind in which it reigns sovereign” (17).

What then, is the nature of this experience? In his second speech Schleiermacher famously notes that "praxis is an art, speculation is a science, religion is the sensibility and taste for the infinite" (23). That Schleiermacher connects religion to "sensibility and taste for the infinite," that is, with feeling is absolutely central, since it positions him along with the Romantics against Fichte, for whom the activity of consciousness was the first principle of philosophy. For Kant, let us remember, there are "two stems of human cognition, which may perhaps arise from a common but to us unknown root, namely sensibility and understanding, through the first of which objects are given to us, but through the second of which they are thought” (A15/B29). We can 
think of the split between the Romantics and the followers of Fichte as having to do with how to characterize original consciousness. What is most central to it, spontaneity or receptivity? Does it know its existence as it achieves itself through its own positing, or is there something yet more central through which the self simply recognizes its own facticity and its own absolutely conditioned character? If the latter, the self experiences an existence that has already been granted to it; the self does not simply achieve itself and is not its own ground. For Schleiermacher in Christian Faith, God is the "Whence of our passive and active existence.” But how does the self cognize its own existence? Schleiermacher argues that the self has a direct and immediate awareness of itself in both its passivity and activity; this awareness is more central than the awareness the self has of itself in its reflected representations. According to Kant's terminology, because this is an immediate awareness of the self in its particularity and specificity, it is an intuition. Concepts, on the other hand, are merely reflected representations in principle applicable to an infinite number of individuals. And Kant had argued that for human beings all intuition is sensible, that is, because human beings cannot produce individual objects through thinking them, but can only achieve concepts of them, human cognition is incapable of intellectual intuition. Only God is capable of an intellectual intuition, producing that which God thinks. For finite human cognition, on the other hand, individuals are given directly to cognition, through sensation (and thereby not through a concept); they are intuited. As Schleiermacher notes, "Intuition is and always remains something individual, set apart, the immediate perception, nothing more" (26). The difference between Schleiermacher and Fichte in characterizing the cognition of original consciousness is therefore of great significance. For Fichte, we have an intellectual intuition of original consciousness. It is intellectual for we achieve ourselves in our very positing of ourselves, and it is an intuition for we know ourselves in our particularity through this very activity. For Schleiermacher, on the other hand, original consciousness is given through intuition and feeling. In Christian Faith, he would speak of the feeling of absolute dependence, an experience the self has of itself in its conditioned immediacy that is the jumping off point for faith.

The battle with Fichte stands front and center of Schleiermacher's characterization of religious experience in On Religion. He asks "And how will the triumph of speculation, the completed and rounded idealism, fare if religion does not 
counterbalance it and allow it to glimpse a higher realism than that which it subordinates to itself so boldly an for such good reason.” And echoing Jacobi, he answers, "Idealism will destroy the universe by appearing to fashion it; it will degrade it to a mere allegory, to an empty silhouette of our own limitedness" (24). In contrast to idealism and and naïve empiricism, Schleiermacher advocates a "higher realism" based on the feeling of Being given to original consciousness. This is no naïve realism advocating the contradictory notion that things as they are in themselves might be given to consciousness; Schleiermacher's "higher realism" has to with givenness of Being in original consciousness.

Schleiermacher's stress on givenness of Being is nowhere more clearly evident than in his famous passage on the origin of the religious experience. It cannot be stressed enough that for Schleiermacher the ground of religion lies in intuition and feeling, that is in a receptivity to what is given, namely, to the IT IS of existence. Religion does not have to do with spontaneity or the activity of thinking so stressed by Fichte. And so we find Schleiermacher speaking of the subject/object split key to the achievement of self-consciousness in terms of the split between intuitions and feeling, and not in terms of the activity of original consciousness positing itself. He mourns that he "cannot speak of both other than separately," and that "the finest spirit of religion is thereby lost" for his speech:

But reflection necessarily separates both [intuition and feeling]; and who can speak about something that belongs to consciousness without first going through this medium? Not only when we communicate an inner action of the mind, but even when we merely turn it into material for contemplation within ourselves and wish to raise it lucid to consciousness, this unavoidable separation immediately occurs. This state of affairs intermingles with the original consciousness of our dual activity, what predominates and functions outward and what is merely sketching and reproducing, which seems rather to serve things. Immediately upon this contact the simplest matter separates itself into two opposing elements, the one group combining into an image of an object, the other penetrating to the center of our being, there to effervesce with our original drives and to develop a transient feeling. (31) 
While feelings have to do with how we have been affected and therefore with our own states, intuitions are referred to individual things distinct from ourselves; as Schleiermacher notes they combine "into an image of an object." The idea is related to one already put forward by Kant in his discussion of the third analogy: each of our empirical representations must have a double reference (A189-90/B234-5). The first is to the subject of representation: each representation is a modification of the mind of the subject. The second is to the intentional object of representation: the representation is of an object and is attributed to it. Schleiermacher argues that in "the first stirring of the mind" there is a moment of unity before the split between feeling (referred to the subject) and intuition (referred to the object): "Intuition without feeling is nothing and can have neither the proper origin nor the proper force; feeling without intuition is also nothing; both are therefore something only when and because they are originally one and unseparated" (30). In this moment of original unity subject and object are one; it is a moment prior to reflection, one in which the I and the not I are not yet distinguished from one another and in which there is not yet consciousness of self:

That first mysterious moment that occurs in every sensory perception, before intuition and feeling have separated, where sense and its objects have, as it were, flowed into one another and become one, before both turn back to their original position - I know how indescribable it is and how quickly it passes away. . . . . Even as the beloved and ever-sought for form fashions itself, my soul flees towards it; I embrace it, not as a shadow, but as the holy essence itself. I lie on the bosom of the infinite world. At this moment I am its soul, for I feel all its powers and its infinite life as my own; at this moment it is my body, for I penetrate its muscles and its limbs as my own, and its innermost nerves move according to my sense and my presentiment as my own... This moment is the highest flowering of religion. (32)

While in original consciousness alone there is no self-consciousness, there is, nevertheless, consciousness. It is a consciousness of a feeling of Being in which there is only unity with all that is. The moment prior to reflection in which the mind is fully quiet and not yet full of itself is "the natal hour of everything living in religion" (32).

From this several things follow. First, the infinite can only be given in the immediacy of original consciousness. The achievement of self-consciousness is always a 
limited one, and what is reflected in consciousness of self can never express the fullness of what is given in the immediacy of our active and receptive existence. Fichte's focus on the virtuosity of the I, on its activities and reflections, leads only to self-deception and self-destruction, for the self can never capture itself; it is always too great for its reflections: "Can we, advancing from one limited work to another, really exhaust our whole infinite energy? Will not, rather, the greater part of it lie unused, and consequently turn away and consume us? How many of you go to ruin simply because they are too great for themselves?” (47). How can this ruin be avoided? Only through resting in the passivity of original consciousness, in the fullness of Being and its ground.

Second, because religion is born in intuition and feeling, it resists systematization. ${ }^{37}$ Systematization requires concepts, themselves depending upon reflection. But the moment reflection comes into the picture, the heart of religion has been covered over and its essence lost. Concepts are general representations and they cannot capture the particular qua individual. The particular can only be given in the religious experience itself. Hence Schleiermacher argues that religion "stops with the immediate experience of the existence and action of the universe, with the individual intuitions and feeling." Religion knows nothing about "derivation and connection;" that is "what its nature most opposes," for everything in religion "is immediate and true for itself" (26). Once the drive to systematize has come upon the scene, we are left only with the "dead slag," which was "once the glowing outpouring of the inner fire that is contained in all religions" (99).

Third, the person who has had a genuine religious experience knows that it can never be adequately conceptualized or systematized. The religious experience is fleeting and has passed as soon as reflection sets in; the person who has lived religion is therefore very tolerant of the religious experiences and views of others: "Each person must be conscious that his religion is only part of the whole, that regarding the same objects that affect him religiously there are views just as pious and, nevertheless, completely different from his own, and that from other elements of religion intuitions and feelings flow, the sense for which he may be completely lacking” (27). Since religion

37 For further discussion of these points, see my "Metaphysical Realism and Epistemological Modesty in Schleiermacher's Method," in The Persistence of the Sacred in Modern Thought, edited by Chris Firestone and Nathan A. Jacobs, Notre Dame: University of Notre Dame Press, 2012. 
is ultimately rooted in experience, there may be very different religious practices foreign to one's own that give rise to it in others. Recognition of the effectiveness and importance of those practices for others takes nothing away from the validity of one's own religious experience, which immediately validates itself.

Fourth, how the religious experience is conceptualized is not of supreme importance. What is important is the religious experience itself. Schleiermacher notes that "belief in God depends on the direction of the imagination," and that "the idea of God does not rank as high as you think” (53). Truly religious persons are content to live and let live; they have no need to force the idea of God upon anyone, for they rest in the quiet confidence of God's activity; hence "among truly religious persons there have never been zealots, enthusiasts or fanatics for the existence of God” (53).

Let me close with some final reflections. Fundamental differences in the reception of Kant between the Romanticism and Idealism on the question of consciousness and its access to the Absolute came to a head in the differences between Hegel's absolute philosophy and philosophy of religion and Schleiermacher's Christian Faith. Hegel took Fichte's foundational insights on consciousness and applied them to Absolute Mind: the logic of Absolute Mind conditions its actualization. Since this logic is repeated in human consciousness, we are able to rationally plumb the depths of the Absolute and recognize ourselves as its expression and realization. There are no things in themselves, unknown and unknowable, and hidden from knowledge. This was an absolute and totalizing philosophy. The view was antithetical to Schleiermacher, who, along with the other Romantics, had worked out a penetrating critique of Fichte's method. Once Hegel arrived at Berlin, the conflict between the two came to a head: Harnack notes that Schleiermacher barred Hegel from the Berlin Academy of Sciences fearing "the despotism of the Hegelian philosophy." ${ }^{8}$ Tensions between the two men gradually worsened and finally came to a head in 1822 when Hegel, in a preface to a book by Hinrichs, quipped that if religion is grounded in the feeling of absolute dependence, then "a dog would be the best Christian" (90-1). For Hegel religion must be superseded: it remains at the level of "picture thinking" and needs to be transcended by philosophy. For Schleiermacher, on the other hand, Being remains an enigma. What is given to us is consciousness of our conditioned character and radical finitude; this is

${ }^{38}$ Cited in Crouter, Between Enlightenment and Romanticism, 88. 
the jumping off point for faith. In his 1802 letter to Reiner, Schleiermacher averred that he had "become a Herrnhuter again, but of a higher order." 39 This is reflected in his understanding of the feeling of absolute dependence, which already contains an expression of faith and piety. Our facticity confronts us as an enigma to ourselves. The feeling of absolute dependence is a response to this enigma; as Jacobi would put it, it is a jump into "the abyss "of the divine mercy. Faith, and not knowledge stand at the heart of Schleiermacher's method. This was the legacy of the Romantics to the theory of religion.

${ }^{39}$ Life of Schleiermacher, edited and translated by Federica Rowan. London: Smith Elder and Co. 1860, I: 283-4. 